\title{
ADAPTASI PSIKOLOGI KLIEN DENGAN KANKER PAYUDARA DI RS NURUL HASANAH KUTACANE TAHUN 2021
}

\author{
Nurjannah', Nurhasanah Sym² \\ ${ }^{1,2}$ STIKes Nurul Hasanah Kutacane \\ Email: sweat.memorian@gmail.com,symnurhasanah@gmail.com
}

\begin{abstract}
Breast cancer is a disease that can be experienced by women all over the world and affects every aspect of human life, especially psychosocial aspects. The main psychosocial problems experienced by breast cancer clients are ineffective coping, body image and impaired sexual function. This descriptive study aims to identify psychosocial adaptations of breast cancer clients at Nurul Hasanah Kutacane Hospital. The study was conducted from January 12 to June 4, 2021. Determination of the number of samples using total sampling with the number of samples of 25 people. The research instrument used a selfcreated questionnaire by researchers consisting of demographic data and psychosocial adaptations of breast cancer clients. The questionnaire has been tested for reliability using KR 20 with a result of 0.7029 . The results showed that most of the 24 respondents (96\%) had adaptive psychosocial adaptations. This research has implications for educational institutions, nursing practices. The conclusion of this study is that the majority of psychosocial adaptation clients with breast cancer are 24 people (80\%) and the non-adaptive minority are 6 people (20\%).
\end{abstract}

Keywords : Psychological adaptation, breast, breast cancer

PENDAHULUAN

Kanker payudara merupakan penyakit yang dapat dialami oleh wanita diseluruh dunia dan merupakan masalah yang signifikan yang dapat menimbulkan kesengsaraan dan kematian pada manusia (Witdiawati: et al., 2018). Berdasarkan data GLOBOCAN, Internasyional Agency for Research on Cancer (IARC), pada tahun 2012 terdapat 14.067.894 kasus baru kanker dan 8.201.575 kematian akibat kanker diseluruh dunia. Pada tahun 2012 kanker menjadi penyebab kematian 8,2 juta orang. Angka penderita kanker diperkirakan akan meningkat setiap tahunnya dan diperkirakan mencapai 23,6 juta kasus per tahun pada 2030. Kanker hati, paru, perut, kolorektal dan kanker payudara adalah penyebab terbesar kematian akibat kanker setiap tahunnya. (Infodatin, 2016)

Kanker payudara merupakan penyakit yang dapat mempengaruhi setiap aspek kehidupan manusia baik secara individu maupun supra sistemnya (keluarga dan lingkungan sosial). Setiap jenis pengobatan terhadap penyakit ini dapat menimbulkan masalah - masalah 
fisiologis dan psikososial pada klien. Masalah psikososial utama adalah koping yang tidak efektif, gangguan gambaran diri, dan gangguan fungsi seksual (Zuhri $\&$ IndScript Creative, 2014).

Penelitan Pratiwi dkk tahun 2017 menunjukkan sebagian dari responden mengalami state anxiety sedang $(59,8 \%)$, dan sebagian responden mengalami trait anxiety sedang $(54,6 \%)$. Berdasarkan faktor yang mempengaruhi kecemasan, faktor ancaman sistem diri merupakan faktor yang mendominasi kecemasan pada pasien kanker payudara yang menjalani kemoterapi. Ancaman sistem diri yang mendominasi ini dapat memengaruhi peran dari pasien, sehingga perlu adanya upaya untuk menurunkan kecemasan dengan memperhatikan berbagai faktor yang memengaruhi.(Pratiwi et al., 2017).

Sikap ataupun reaksi orang dalam menghadapi kanker yang mengidap pada dirinya berbeda satu sama lain dan individual sifatnya. Hal ini tergantung pada sampai berapa jauhkah kemampuan individu yang bersangkutan untuk beradaptasi terhadap situasi yang mengancam kehidupannya. Hal tersebut juga tergantung pada usia, kematangan emosional, keadaan sosio, ekonomi dan juga pengetahuan mengenai kanker. Berbagai faktor psikososial tersebut akan mempengaruhi kondisi jiwa seseorang untuk bereaksi. Sebagaimana penelitian Steven Keller (2019) telah menemukan keterkaitan antara stres psikososial, depresi, imunitas, dan kesehatan fisik yang mengarah pada resiko munculnya sel-sel kanker (Hawari, 2006)

Berdasarkan hasil studi pendahuluan peneliti kepada 5 orang wanita yang terkena kanker payudara di Rumah Sakit RS Nurul Hasanah Kutacane terdapat 3 orang yang mengalami mal adaptif dengan ditandai harga diri yang rendah dan sulit beradaptasi karena perubahan citra tubuh. Dari urian tersebut dapat diketahui bahwa adaptasi psikososial sangat penting bagi pasien kanker payudara. Oleh karena itu peneliti tertarik untuk melakukan penelitian tentang adaptasi psikososial pasien kanker payudara di Rumah Sakit Nurul Hasanah Kutacane Tahun 2021.

\section{METODE}

Desain yang digunakan dalam penelitian ini adalah desain deskriptif dimana peneliti berusaha mengetahui adaptasi psikososial klien dengan kanker payudara. Penelitian dilakukan pada tanggal 12 Januari - 04 Juni 2021 di RS Nurul Hasana Kutacane Tahun 2021. Penelitian Populasi penelitian ini adalah 
pasien dengan kanker payudara sebanyak 30 orang.

Sampel pada penelitian ini sebanyak 30 orang dengan Teknik total sampling.

\section{HASIL DAN PEMBAHASAN}

Adaptasi psikososial klien dengan kanker payudara

Tabel 1. Adaptasi psikososial klien dengan kanker payudara.

\begin{tabular}{llll}
\hline No & Adaptasi psikososial & $\mathbf{n}$ & \% \\
\hline 1 & Adaptif & 24 & 80 \\
2 & Non Aadaptif & 6 & 20 \\
\hline & Total & $\mathbf{3 0}$ & $\mathbf{1 0 0}$ \\
\hline
\end{tabular}

Berdasarkan Tabel 1 diatas menunjukkan bahwa mayoritas adaptasi psikososial klien denga kanker payudara sebanyak 24 orang $(80 \%)$ dan minoritas non adaptif sebanyak 6 orang (20\%).

Koping Klien Kanker Payudara di RS Nurul Hasanah Kutacane.

Tabel 2. Koping klien dengan kanker payudara

\begin{tabular}{llll}
\hline No & Koping & n & \% \\
\hline 1 & Diskusi & & \\
\hline & Ya & 24 & 80 \\
\hline & Tidak & 6 & 20 \\
\hline & Total & 30 & 100 \\
2 & Aktivitas & & \\
\hline & Ya & 20 & 68 \\
\hline & Tidak & 10 & 32 \\
\hline \multicolumn{2}{l}{ Total } & $\mathbf{3 0}$ & $\mathbf{1 0 0}$ \\
\hline 3 & Melupakan Penyakit & & \\
\hline & Ya & 24 & 80 \\
\hline
\end{tabular}

\begin{tabular}{|c|c|c|c|}
\hline & Tidak & 6 & 20 \\
\hline & Total & 30 & 100 \\
\hline \multirow[t]{4}{*}{4} & Tindakan Kemoterapi & & \\
\hline & Ya & 25 & 84 \\
\hline & Tidak & 5 & 16 \\
\hline & Total & 30 & 100 \\
\hline \multirow[t]{4}{*}{5} & $\begin{array}{l}\text { Gangguan } \\
\text { Tubuh }\end{array}$ & & \\
\hline & $\mathrm{Ya}$ & 28 & 92 \\
\hline & Tidak & 2 & 8 \\
\hline & Total & 30 & 100 \\
\hline \multirow[t]{4}{*}{6} & $\begin{array}{l}\text { Penampilan } \\
\text { Menarik }\end{array}$ & & \\
\hline & $\mathrm{Ya}$ & 23 & 76 \\
\hline & Tidak & 7 & 24 \\
\hline & Total & 30 & 100 \\
\hline \multirow[t]{4}{*}{7} & Masih Merawat Diri & & \\
\hline & $\mathrm{Ya}$ & 22 & 72 \\
\hline & Tidak & 8 & 28 \\
\hline & Total & 30 & 100 \\
\hline
\end{tabular}

Dari aspek koping yang digunakan klien kanker payudara sebanyak 24 orang $(80 \%)$ responden menyatakan bahwa sering berdiskusi dengan keluarga tentang resiko terburuk dari penyakit kanker payudara. Sebanyak (68\%) responden menyatakan tetap beraktifitas seperti biasa meskipun sudah terkena penyakit kanker payudara. Sebanyak (80\%) responden menyatakan bahwa mencoba melupakan penyakit kanker payudara dengan menjauhkan dari pikirannya. Sebanyak (84\%) responden menyatakan bahwa menjalankan tindakan kemoterapi sesuai dengan jadwal untuk mempercepat proses penyembuhan penyakit kanker payudara.

Hasil penelitian gangguan citra tubuh, menunjukkan bahwa responden 
menyatakan sebanyak (92\%) merasa sering cepat lelah dan nyeri pada payudaranya. Sebanyak (76\%) responden menyatakan bahwa penampilannya masih menarik meskipun sudah terkena penyakit kanker payudara. Sebanyak (72\%) responden menyatakan bahwa akan tetap merawat dirinya dengan baik sebagaimana sebelum terkena penyakit kanker payudara.

Adaptasi psikososial adalah cara individu untuk menyesuaikan status mental dan emosionalnya terhadap perubahan - perubahan yang terjadi didalam lingkungan sosialnya. Pada umumnya datang ke rumah sakit untuk menjalankan pengobatan kemoterapi yang berulang sehingga sudah mempunyai koping yang positif terhadap penyakitnya dan mendapat dukungan penuh dari pihak keluarga. Hasil penelitian ini tidak sesuai dengan penelitian (Nurachmah, 2014) yang menyatakan banyak klien kanker payudara yang mengalami kesulitan untuk menyesuaikan diri terhadap perubahan fisik akibat dampak pengobatan. Dan menurut (Hawari, 2006), klien kanker payudara akan mengalami gangguan penyesuaian (adjustmen disorder) yang ditandai dengan perilaku mal adaptif yakni klien tidak mampu lagi beradaptasi dengan lingkungannya.
Di sini akan dibahas bagaimana strategi koping yang paling sering digunakan responden klien kanker payudara yakni "kebersamaan" dimana sebanyak 20 orang (68\%) klien sering berdiskusi dengan keluarga tentang resiko terburuk dari penyakit kanker payudara. Manakala keluarga tahu bahwa salah satu keluarganya menderita kanker, maka lazimnya pihak keluarga tidak dapat melepas diri dari keterlibatan dalam menghadapi penderitaan klien kanker. Peranan keluarga amat penting, pihak keluarga yang penuh pengertian dan kooperatif dengan pihak perawatan dan memberikan dorongan moril penuh kepada penderita kanker, akan banyak membantu dalam penatalaksanaan penderita kanker (Hawari, 2006). Pendapat diatas didukung oleh Musbikin (2015) yang menyatakan bahwa wanita biasanya mengatasi masalah dengan berbicara kepada teman atau kerabatnya.

Strategi koping lain yang sering digunakan klien kanker payudara yakni "Mencoba melupakan penyakit dengan menjauhkannya dari pikiran" dimana sebanyak 24 orang responden $(80 \%)$ klien kanker payudara mencoba melupakan penyakitnya, ini sesuai dengan strategi koping "Supresi" yang digunakan klien kanker. 
Strategi koping lain yang juga digunakan klien kanker payudara adalah "Tetap beraktifitas seperti biasa meskipun sudah terkena penyakit kanker payudara“ dimana sebanyak 20 orang responden $(68 \%)$ klien kanker payudara mencoba tetap beraktifitas seperti biasa, ini sesuai dengan strategi koping “ Mengisar”(tetap sibuk, mengalihkan perhatian pada kegiatan), yang digunakan klien kanker menurut (Nurachmah, 2014)

Citra tubuh adalah sikap seseorang terhadap tubuhnya secara sadar dan tidak sadar yang mencakup persepsi dan perasaan tentang ukuran, bentuk, fungsi dan potensi tubuh saat ini dan masa lalu (Keliat \& Asih, 2008)

Dari hasil penelitian yang dilakukan, sebanyak 28 orang responden (92\%) klien kanker payudara merasa sering cepat lelah dan nyeri pada payudaranya. Hal ini sesuai dengan proses kanker menurut (Keliat \& Asih, 2008) yang menyatakan bahwa proses kanker akan menimbulkan perubahan citra tubuh yakni nyeri, kelelahan, kelemahan, mudah terinfeksi, berat badan berkurang. Hal ini sesuai dengan penelitian Maddux dan Lewis (2015) dalam (Nurachmah, 2014)), yang menyatakan wanita pengidap kanker payudara mengalami perubahan citra tubuh.
Selain itu 23 orang responden (76\%) klien kanker payudara menyatakan "Penampilannya masih menarik meskipun sudah terkena kanker payudara”. Dalam penelitian ini memang tidak ada alasan yang cukup kuat untuk mendukung hasil penelitian ini. Tetapi peneliti hanya bisa berasumsi bahwa responden memiliki koping yang adaptif dan dukungan positif dari suami dan keluarga.

Selain itu 18 orang responden $(72 \%)$ klien kanker payudara menyatakan "Tetap merawat diri dengan baik sebagaimana sebelum terkena penyakit kanker payudara", Hal ini disebabkan karena responden merasa semua yang ada ditubuh responden merupakan anugrah dari Tuhan yang harus tetap dijaga.

\section{KESIMPULAN DAN SARAN}

\section{Kesimpulan}

Kesimpulan penelitian ini adalah mayoritas adaptasi psikososial klien denga kanker payudara sebanyak 24 orang (80\%) dan minoritas non adaptif sebanyak 6 orang (20\%)

\section{Saran}

Bagi institusi keperawatan diharapkan hasil penelitian ini dapat dijadikan sebagai data tambah yang bisa digunakan dalam pembuatan materi pembelajaran di keperawatan mternitas dalam menerapkan asuhan keperawatan 
bagi pasien kanker payudara terutama dalam aspek psikososial.

\section{DAFTAR PUSTAKA}

Hawari, D. (2006). Global effect HIV/AIDS : dimensi psikoreligi. Fakultas Kedokteran, Universitas Indonesia.

Infodatin. (2016). Bulan Peduli Kanker Payudara.

Keliat, B. A., \& Asih, Y. (2008). Gangguan koping, citra tubuh, dan seksual pada klien kanker - Google Books.

EGC. https://www.google.co.id/books/editi on/Gangguan_koping_citra_tubuh_d an_seksual/j4qjAQAACAAJ?hl=id

Nurachmah, E. (2014). Dampak Kanker Payudara dan Pengobatannya Terhadap Aspek Bio-psiko-spiritual Klien yang Berpartisipasi Dalam Kelompok Pendukung. Jurnal Keperawatan Indonesia, 2(6). https://doi.org/10.7454/jki.v2i6.90

Pratiwi, S. R., Widianti, E., \& Solehati, T. (2017). Gambaran Faktor-Faktor yang Berhubungan dengan Kecemasan Pasien Kanker Payudara dalam Menjalani Kemoterapi. Jurnal Pendidikan Keperawatan Indonesia, $3(2)$, 167. https://doi.org/10.17509/jpki.v3i2.94 22
Witdiawati:, Rahayuwati, L., \& Sari, S. P. (2018). Studi EthnographyEthnonursing - Google Books. Unpad Press. https://www.google.co.id/books/editi on/Studi_Ethnography_Ethnonursing /3TSLDwAAQBAJ?hl=id\&gbpv=1 $\& d q=$ kanker+payudara $\&$ printsec $=$ fro ntcover

Zuhri, T. W., \& IndScript Creative. (2014). Kanker bukan akhir dunia: (kiat-kiat cerdas perempuan menghadapi kanker). 144. 